\title{
Is it all processing all the way down?
}

\section{Citation}

Orfitelli, Robyn, and Maria Polinsky. 2013. "Is It All Processing All the Way Down?" Linguistic Approaches to Bilingualism 3 (3) (January 1): 335-340. doi:10.1075/lab.3.3.11orf.

\section{Published Version}

doi:10.1075/lab.3.3.11orf

\section{Permanent link}

http://nrs.harvard.edu/urn-3:HUL.InstRepos:37108750

\section{Terms of Use}

This article was downloaded from Harvard University's DASH repository, and is made available under the terms and conditions applicable to Open Access Policy Articles, as set forth at http:// nrs.harvard.edu/urn-3:HUL.InstRepos:dash.current.terms-of-use\#OAP

\section{Share Your Story}

The Harvard community has made this article openly available.

Please share how this access benefits you. Submit a story.

Accessibility 


\section{Is it all processing all the way down?}

\section{Commentary on the paper by William O'Grady "The illusion of language acquisition"}

\section{Robyn Orfitelli (UCLA) and Maria Polinsky (Harvard)}

One of the primary goals of linguistics is to determine which aspects of language structure and use are language-specific and which ones are domain-general. We may be unified by the desire to separate explanations into domain-general cognitive mechanisms and languagespecific mechanisms, but the way we achieve this separation differs depending on one's theoretical persuasion. A strict nativist-who is unlikely to exist-would posit that all of language is part of Universal Grammar (UG), while a strict emergentist would claim that none of language is domain-specific and that language arises entirely from general cognitive mechanisms. The Amelioration Hypothesis (AH) is a specific case of strict emergentism, positing that language arises entirely out of a desire to limit the processing burden of language production and comprehension. According to the AH, all language use by adults may be boiled down to processing simplification, and the developmental steps of first and second language acquisition aim to ease the processing burden of language.

UG and AH are decidedly radical. Pushing a radical position to its extreme is the best way to see how well it works, and this hypothesis test is useful when both approaches handle the same data. Our goal here is not to keep score for different frameworks, but rather to emphasize empirical data critical to the foundation of either theory.

In our commentary, we would like to emphasize the point that when seeking support for a particular approach, it is important to identify cases that this approach, but not the alternative, can account for. We believe that such cases are still outstanding. In what follows, we will first consider an instance in language development that $\mathrm{UG}$ and $\mathrm{AH}$ explain equally well. We will next discuss two instances in acquisition where $\mathrm{AH}$ does not describe the steps that children go through. And finally, we will discuss a case in adult grammar where UG, but not the AH, can describe the data. If this case leads to a future refinement of the $\mathrm{AH}$, that of course will be an excellent development.

UG: 1, AH: 1. In his work, O'Grady provides many examples where the Amelioration Hypothesis suffices to explain data that nativists have explained using UG, including the development and use of scope relationships in English and Korean. In fact, the AH fares particularly well in its approach to such cases of ambiguity resolution. In addition to the cases considered by O'Grady, the AH could readily explain speakers' online preference for the lower attachment site in cases of attachment ambiguity (Frazier and Fodor, 1978; a.o.), as in (1).

(1) The student photographed the fan of the actress who was looking happy

\footnotetext{
* This material is based upon work supported with funding from the United States Government. Any opinions, findings and conclusions or recommendations expressed in this material are those of the authors and do not necessarily reflect the views of any agency or entity of the United States Government. We are solely responsible for any remaining errors in the paper.
} 
Even up through the age of 5 years, children's preference for minimal attachment remains so strong that they will ignore contextual cues that point to a different attachment site (Goodluck and Tavakolian, 1982; Felser et al., 2003). ${ }^{1}$

Another domain where the AH fares very well has to do with the acquisition of some word order principles. For example, Goodall (2007) also appeals to the interaction of processing ease and syntactic optionality to explain why Spanish-acquiring children master inversion in $w h$ questions earlier than English children. His point is that English children have to tap into their grammatical knowledge, whereas Spanish learners tap into processing, and that explains the difference in the acquisition trajectories of wh-questions in two languages. Although nativist explanations have been provided for the Spanish data, they are also consistent with the reduction of working memory load, as predicted by the AH.

Challenges to the AH. It is not our goal to present a long list of problems that the AH may face. Instead, we would like to introduce a general principle which could guide the future testing of the $\mathrm{AH}$. Since the main tenet of the $\mathrm{AH}$ is that language use and acquisition are driven by the need for processing simplicity, it is critical to consider linguistic situations where speakers have a choice between two or more options that differ in terms of the processing load. If speakers (or language learners) always choose in favor of the least processing effort, that would be a strong argument in favor of the $\mathrm{AH}$. Let us now present two instances where empirical evidence does not cooperate with the $\mathrm{AH}$ : the acquisition of wh-questions and clitics. We would like to note that while O'Grady's hypothesis, as presented in the keynote, is mainly about comprehension, our illustrative data come primarily from production; the data are still relevant because the $\mathrm{AH}$ is a broad-based, general hypothesis of language, which will encompass production as well as comprehension.

There is general agreement that a fronted wh-word invokes a discontinuous dependency: the parser needs to wait until the subcategorizing predicate in order to build the dependency. (The actual syntax of such a dependency is not important here; it could be A-bar movement or longdistance anaphoric dependency — nothing hinges on a particular analysis, since the dependency is long-distance no matter what.) Leaving a wh-word in situ would minimize processing costs by eliminating the long-distance dependency. However, even in languages where speakers have a choice between wh-movement (2a) and wh-in-situ (2b) (e.g., Romance, Basque), children initially prefer moving the wh-word to the front in both short and long wh-questions (Weissenborn et al., 1995; Jakubowicz \& Strik, 2008; Junkal Gutierrez Mangado, 2009). This pattern is unexpected under the $\mathrm{AH}$.
a. Où dis-tu que Marie va?
where say-you that Marie goes
b. Tu dis que Marie va où?
you say that Marie goes where?
'Where do you say that Marie is going?'

\footnotetext{
${ }^{1}$ Snedeker \& Trueswell (2004) present compelling arguments that lexical bias plays a large role in children's ambiguity resolution, possibly even overriding minimal attachment. We believe that this account is compatible with the AH, or at the very least, with emergentism, and so we will remain agnostic as to whether lexical bias operates exclusively in conjunction with minimal attachment in child processing.
} 
The second example is observed in the acquisition and use of direct (3a) and indirect (3b) object clitics in several Romance languages, in particular Romanian:
a. Moş Crăciun $i$
-a adus
Santa Clause him/her-DAT
'Santa brought the girl a present.'
b. Elefantul l- a stropit pe băiat
Elephant-the him-ACC- has sprinkled on boy
'The elephant sprinkled the boy.'

(Babyonyshev \& Marin, 2006: 18)

Romanian

un cadou fetiţei

.

. 
b. Mary glued John to herself $/ *$ himself.

c. Near himself $f_{i}$ is where $\mathrm{John}_{\mathrm{i}}$ found it.

d. Which author $\mathrm{i}_{\mathrm{i}}$ wrote [every article about politics $]_{\mathrm{j}}$ himself $\mathrm{f}_{\mathrm{i}} /$ itself $_{\mathrm{j}}$ ?

When we consider languages other than English, the AH runs into further difficulties. In languages with prepositional possessive, such as Romance, the DP closest to the anaphor cannot be the binder, so the AH would need to account differently for the English (5) and the French (6).

$$
\begin{aligned}
& \text { La soeur }{ }_{j} \text { de Marie }{ }_{i} s_{j} *_{i}{ }^{\prime} \text { est vue. } \\
& \text { the sister } j_{j} \text { of } \text { Marie }_{i} \quad \text { self }_{j} *_{i} \text { is seen } \\
& \text { 'Marie's sister saw herself/*Marie.' }
\end{aligned}
$$

Another problem case occurs in languages with verb-object-subject (VOS) word order, such as Malagasy, in which the bindee linearly precedes the binder (7). Without making reference to structural relationships such as c-command, it is not clear how to accommodate such data. Note also that even if we reverse the rule for binding, allowing it to operate from right to left, the binder and the anaphor are separated by another expression, similar to the English examples in (5):

$$
\begin{array}{clllll}
\text { Mihevitra } & \text { ny } & \text { tena-ny } & \text { ho } & \text { hajain'i Soa } & \text { Rakoto } \\
\text { think } & \text { DET } & \text { self-3POSS } & \text { PRT } & \text { respect.THEME_TOP'by Soa } & \text { Rakoto }
\end{array}
$$

'Rakoto thinks himself to be respected by Soa.' (Rackowski \& Travis, 2000: 133)

Let us conclude. It is quite possible that future work will uncover ways of accounting for the phenomena that we have presented as challenging to the $\mathrm{AH}$, but in order for that to happen, it will be important to base our comparison between the radical nativist and radical emergentist approach on a broader range of empirical facts. As we arrive at a better understanding of the interplay between grammar and parser, all sides stand to gain in the process. It may indeed not be necessary to advocate either a radical nativist or a maximalist emergentist approach to language (even when the arguments for either approach are only preliminary). Instead, we may adopt a combination of the two. We believe that this stance, which has been widely adopted in recent years, may prove fruitful in reconciling the benefits of the $\mathrm{AH}$ with the challenges presented here.

\section{References}

Babyonyshev, M., \& Marin, S. (2006). Acquisition of Pronominal clitics in Romanian. Catalan journal of linguistics, 5, 17-44.

Chomsky, N. (1981). Lectures on Government and Binding, Foris, Dordrecht.

Chomsky, N. (1986). Knowledge of language: its nature, origin and use, Praeger, New York.

Felser, C., Marinis, T., \& Clahsen, H. (2003). Children's processing of ambiguous sentences: A study of relative clause attachment. Language Acquisition 11, 127-163.

Frazier, L., \& Fodor, J. D. (1978). The sausage machine: A new two-stage parsing model. Cognition 6, 291-325.

Goodall, G. (2007). Inversion in wh-questions in child Romance and child English. In M.J. Cabrera, J. Camacho, V. Déprez, N. Flores, \& L. Sánchez (eds.). Romance Linguistics 2006: 
Selected papers from the 36th Linguistic Symposium on Romance Languages (LSRL), 169182. Amsterdam/Philadelphia: John Benjamins.

Goodluck, H., \& Tavakolian, S. (1982). Competence and processing in children's grammar of relative clauses. Cognition 11, 1-27.

Jakubowicz, C., \& Strik, N. (2008). Scope-marking strategies in the acquisition of long distance wh-questions in French and Dutch. Lang. Speech 51, 101-32.

Junkal Gutierrez Mangado, M. (2009). Asymmetries in the comprehension of wh-movement in L1 Basque. Paper presented at the EHU International Workshop on Ergative Languages, Bilbao. http://laslab.org/junkal

O'Grady, W. (2010). An emergentist approach to syntax. In H. Narrog \& B. Heine (eds.) The Oxford Handbook of Linguistic Analysis, 257-83. Oxford: Oxford University Press.

Rackowski, A., \& Travis, L. (2000). V-initial languages: X or XP movement and adverbial placement. In A. Carnie \& E.Guilfoyle (eds.). The syntax of verb-initial languages, 117-142. Oxford: Oxford University Press.

Snedeker, J., \& Trueswell, J. C. (2004). The developing constraints on parsing decisions: The role of lexical-biases and referential scenes in child and adult sentence processing. Cognitive Psychology, 49(3), 238-299.

Weissenborn, J., Roeper, T., \& de Villiers, J. (1995). Wh-acquisition in French and German: connections between case, Q-features and unique triggers. Recherches Linguistiques 24, 125-55.

Wexler, K. Gavarró, A., \& Torrens, V. (2004). Feature checking and object clitic omission in child Catalan and Spanish. In R. Bok-Bennema, B. Hollebrandse, B. Kampers-Manhe, \& P. Sleeman (eds.). Romance Languages and Linguistic Theory 2002: Selected papers from 'Going Romance', Groningen, 28-30 November 2002, 253-269. Amsterdam: John Benjamins.

UCLA Linguistics Department

3125 Campbell Hall

UCLA

Los Angeles, CA 90095

Robyn Orfitelli

rorfitelli@ucla.edu

Department of Linguistics

Boylston Hall Third Floor

Harvard University

Cambridge, MA 02138

Maria Polinsky

polinsky@fas.harvard.edu 